\title{
Reengineering the Dutch Flower Auctions: A Framework for Analyzing Exchange Organizations
}

\author{
Ajit Kambil • Eric van Heck \\ Information Systems Department, Stern School of Business, New York University, 44 West 4 th Street, \\ New York, New York 10012 \\ akambil@stern.nyu.edu \\ Department of Decision and Information Sciences, Rotterdam School of Management, Erasmus University Rotterdam, \\ P.O. Box 1738, 3000 DR Rotterdam, The Netherlands \\ eheck@fac.fbk.eur.nl
}

\begin{abstract}
$\mathrm{T}$ his paper specifies a generalizable model of exchange processes and develops a processstakeholder analysis framework to evaluate alternative market designs. This framework is applied to analyze a number of information technology initiatives in the Dutch flower markets. The Dutch flower auctions are the world's leading centers for trading cut flowers and potted plants. We undertake a cross-case analysis and apply our framework to analyse successes and failures in the introduction of new IT-based trading mechanisms in these markets. Based on our study, we develop a number of testable propositions on: the separation of physical and informational processes in trading, the responses of stakeholders to changes in available information due to IT initiatives, and economic and incentive conditions required for adoption of new trading processes. Finally, our detailed cases illustrate the institutional and incentive constraints, and complexities encountered in the introduction of new electronic markets.
\end{abstract}

(Electronic Markets; Transaction Costs; Reengineering; Technology Adoption)

\section{Introduction}

Information technology enables new ways of coordinating the exchange of goods and services. Improved communications and processing systems, such as the Internet and video conferencing, allow individuals and organizations to radically re-engineer existing trading processes enabling new forms of electronic commerce and markets.

Markets are real or virtual meeting places where buyers, sellers, and intermediaries meet to exchange or transfer property rights from one party to another. Typically, buyers and sellers confront many different uncertainties and risks in trading. These include the inability to forecast or plan for the future given the traders' bounded rationality and market uncertainty, combined with the potential for opportunism given the divergent interests of different market participants (Williamson 1975, 1985). Markets and other governance mechanisms provide specific information processing capabilities to exchange parties and serve to generate information and trust to reduce the uncertainty and risks inherent in the exchange process (Kambil 1992). To reduce uncertainty and risk, markets as institutions provide specific routines and procedures for coordination, and for the information and guarantees that enable the buyers and sellers to undertake the exchange.

Prior research on the effects of information technol- 
ogy (IT) on exchange organizations and processes typically applied transaction costs and agency theory to predict shifts from hierarchies toward market or other intermediate forms of organizations (Bakos 1991a, Johnston and Lawrence 1988, Malone et al. 1987, Powell 1990). A central argument of these articles was that information technology would improve communications, searches, monitoring, and informationsorting capabilities to reduce transaction costs and allow purchasers to take advantage of production economies available in markets. A critical drawback of this analysis was the definition of markets in abstract economic terms (i.e., markets coordinate economic activity through a price mechanism) without consideration for differences in market organization. For example, some different market types include direct search markets where partners directly seek each other out (e.g., a typical retail fruit and vegetable market), brokered markets where exchange parties employ agents to seek compatible partners (e.g., private placement offerings by investment banks), dealer markets where dealers as intermediaries hold, buy, and sell product inventories (e.g., NASDAQ), and auction markets where traders transact directly through a centralized intermediary (e.g., Sotheby's art auctions). Each of these mechanisms organizes the trading process and related information processing activities in different ways. Thus, we can expect the impact and role of IT can vary across types.

More recently, information systems researchers have examined the impact of information technology on market institutions. Konsynski et al. (1989, 1990, 1992) provided a number of descriptive case studies of electronic markets providing a rich case base for research. Clemons and Weber $(1990,1991)$ examined the effects of computerization on the London Stock Exchange, and Lee (1993) provided a technology to support order matching of complex products. These studies begin to consider the importance of different market types and institutional histories.

Despite the increasing number of cases on electronic markets, a common language and categorization of key processes in a trading system is lacking. Such a categorization is a precondition to building a framework to systematically evaluate and compare the structure and benefits of different markets for various stakeholders. Building on transaction costs and information-processing models (Galbraith 1974, Tushman and Nadler 1978), this paper provides both a model of key exchange processes and a processstakeholder analysis framework for comparing across different market structures. Such a framework is important to managers who must select and design new trading models. It is also important to researchers who want to develop models of how information technology affects exchange organizations and create theories that can be generalized across cases. We illustrate and apply this framework to evaluate different electronic commerce initiatives in the Dutch flower markets. The framework for analysis developed in this paper can apply to the analysis of other market structures.

\section{Exchange: A Process Stakeholder Analysis}

Exchange is a critical subject of study in marketing, economics, finance, and information systems. Building on these disciplines, information systems researchers have typically adopted a number of outcome dimensions to characterize and evaluate markets. For example, Clemons and Weber (1990) characterize financial markets in terms of liquidity, volatility, and transparency. Liquidity is the ability of the market to absorb large orders without significant price changes, indicating the depth and extent of market participation by buyers and sellers. Volatility refers to the variance in day-to-day volumes and prices, and transparency refers to keeping the widest group of buyers informed on current prices and allowing them access to trading. Highly liquid markets with low volatility and high transparency provide stable forums for exchange.

While these outcome characterizations of different market institutions are important, they are not easily generalizable across settings. For example, liquidity is a key indicator of market quality for financial markets but it is an inappropriate measure in the case of Dutch flower auctions. First, the size of any one flower order is limited, so it is hard to evaluate the impact on price of large orders. Second, the flowers are sold from the auction to the buyer without further resale among the 
buyers. Common outcome characterizations such as liquidity do not apply to all market exchange relations. Outcome characterizations also do not help managers evaluate the potential impact of a new information technology innovation on the operations of a trading system, or the costs and benefits to different stakeholders.

A model of key exchange processes is necessary to provide a reference point for comparing the organization of different market institutions. Traditional process classifications of exchange include search, bargaining and negotiation, monitoring, and enforcement processes (Coase 1960, Dahlman 1979). ${ }^{1}$ However, this level of classification does not provide sufficient detail for the comparison of alternative market structures. What is required is a classification of exchange processes that is generalizable, focuses attention on salient dimensions of an exchange relation and provides sufficiently detailed information for effective classification of exchange features into independent process categories. We adapt work by Kambil (1992) to build such a classification scheme grounded in transactions cost and information-processing theories.

\subsection{A Model of Exchange Processes}

Kambil (1992) identifies ten distinct processes that can operate in an exchange relation, providing a basis for a finer grained analysis of market structure and costs. This categorization also recognizes that basic trade processes exist within a wider context of support processes that implement dispute resolution, and other mechanisms to ensure that counterparties to trades will meet their obligations. We adopt, refine, and extend his model into five trade processes (search valuation, logistics, payments and settlements, authentication) and five trade context processes (commun-

\footnotetext{
${ }^{1}$ Coase (1960) states for "a market transaction it is necessary to discover who it is one wishes to deal with, inform people that one wishes to deal and on what terms, conduct negotiations leading up to a bargain, to draw up a contract, to undertake the inspection needed to make sure that terms of the contract are being observed and so on." This specifies a minimum of three sequential activities: search to gather information and determine products and parties to transactions; bargaining and negotiations to determine the terms of exchange; and the construction and adoption of monitoring, policing, and enforcement mechanism to ensure parties will satisfactorily perform the exchange.
}

ications and computing, product representation, legitimation, influence, and dispute resolution). The basic trade processes are distinct processes required in all transactions of goods and services. The trade context processes facilitate and enable or reduce the costs of or "frictions" in the basic processes. Figure 1 illustrates these processes, which are defined and discussed in Tables 1 and 2.

The ten process categories described in Tables 1 and 2 provide parties to an exchange relation with the information processing, coordination, and influence mechanisms required to mitigate uncertainty and exchange-related risks. While we cannot prove that our categorizations define all processes related to exchange, we propose that these categories define the key processes underlying trades. The categories allow systematic identification of processes affected by a specific administrative or technological innovation and enable us to systematically examine and represent the impacts of information technology across interdependent processes and stakeholders in an electronic market.

The implementation and operation of the above processes and systems create transaction costs for different stakeholders to the exchange. Transaction costs and the complexity of these processes increase as products and production become more complex, and as the market environment becomes more uncertain. Transaction costs also increase as exchange parties establish more complex mechanisms to defuse opportunism risks. Traditional economics postulate that firms will choose to organize exchange relations so that they achieve the lowest possible combined transaction and production costs. This would suggest the trading mechanisms with the lowest sum of transaction costs across all the processes will evolve and dominate the market. However, real-market institutions are complex, constituting a meeting point for stakeholders with both convergent and divergent interests. Innovations by a specific stakeholder may reduce overall transactions costs but can increase the costs to other parties. This can result in the failure to adopt a specific technology or administrative innovation in the marketplace. Thus we propose the need for a process-stakeholder analysis to systematically evaluate the effects of technological innovations on specific processes as well as costs and 
Figure 1 Exchange Processes

Reprinted by permission from: "Doing Business in the Wired World,” Ajit Kambil, IEEE Computer, May 1997. (c) IEEE 1997.

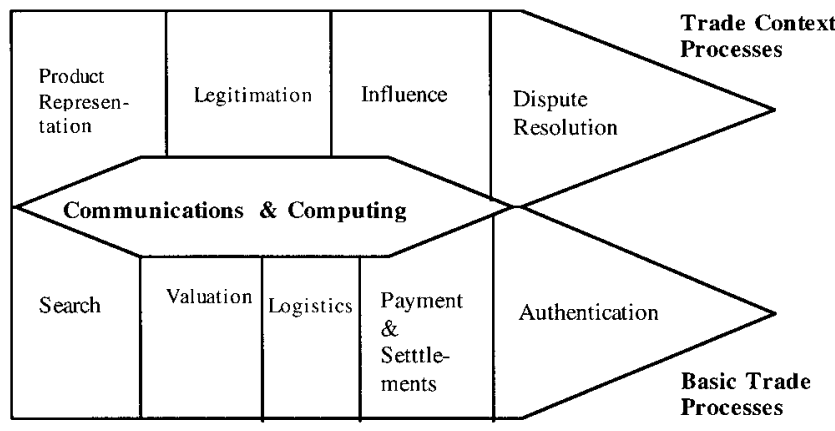

benefits that arise from the innovation on different stakeholders.

Below we develop and illustrate the utility of a process-stakeholder analysis in focusing attention on critical features of trading mechanisms, by using it to systematically represent and evaluate the effects of various information technology initiatives in the Dutch flower auctions (DFA).

\section{The Dutch Flower Auctions}

The Netherlands is the world's leading producer and distributor of cut flowers and potted plants. This industry consists of about 11,000 growers and nearly 5,000 buyers. Growers typically are family businesses, while buyers represent both large and small wholesalers and retailers. The Dutch dominate the world export markets, with 59\% world market share for cut flowers and 48\% world market share for potted plants in 1996. The Dutch flower auctions established and owned by grower cooperatives play a vital role in Holland's leadership of this industry by providing efficient centers for price discovery, and the exchange of flowers between buyers and sellers. The world's two largest flower auctions are the Flower Auction Aalsmeer (VBA) and the Flower Auction Holland (BVH) in Holland. These auctions trade over 30 million flowers and conduct nearly 60,000 transactions daily, generating together over $\$ 2.4$ billion U.S. in annual sales of cut flower and potted products from the Netherlands and other producers such as Israel, Kenya, and Zimbabwe.
Annual sales of the seven Dutch flower auctions exceeded \$2.9 billion U.S. in 1996.

The flower auctions use the "Dutch" auction method for price determination. This method uses a clock, with the clock hand starting at a high price determined by the auctioneer and dropping until a buyer stops the clock by pushing a button to bid for a lot at the price determined by the clock hand. This method was invented by a Dutch cauliflower grower in the 1870s to trade agricultural products. It reduces the time spent by growers at markets and frees them from the task of bidding and price determination, thereby allowing them to focus on production. It also reduces the time buyers spend in bidding or bargaining for goods.

The flower auctions provide a central location for the meeting of buyers, with suppliers allowing for efficiencies in quality control, logistics, and product redistribution. Flower Auction Aalsmeer (VBA) near Schiphol airport and the Flower Auction Holland (BVH) near Rotterdam are located close to major transportation facilities and have some of the largest commercial buildings in the world. Both auctions spread across the equivalent of about 100 soccer fields, each with the capacity to host 2,000 buyers. At the VBA the flower auctions occur in different auction rooms under 13 different clocks. The computerized clock in the auction hall provides buyers with information on the producer, product, unit of currency, quality, and minimum purchase quantity. The flowers are transported through the auction hall and shown below the clock to buyers. When the buyer stops the clock, the auctioneer uses the intercom to ask the buyer how many units of 
KAMBIL AND VAN HECK

Reengineering the Dutch Flower Auctions

Table 1 Description of Basic Trade Processes

\begin{tabular}{ll} 
Process & Description of Basic Trade Processes \\
\hline
\end{tabular}

1. Search

The information gathering and evaluation process undertaken by buyers and sellers to identify opportunities. A trading opportunity consists of a supplier willing to offer a good and a buyer interested in purchasing the good. Thus search processes identify potential suppliers, goods, and customers willing to purchase the goods. Different market mechanisms implement varied methods and venues to identify trading opportunities. Different search methods allocate different search costs to buyers, sellers, or intermediaries.

2. Valuation (Price Negotiation)

3. Logistics

4. Payment and Settlements

5. Authentication
The process and methods of negotiating and discovering a purchase or sale prices for a product. A variety of different price discovery and bidding processes exist that differentially attributes costs to buyers, sellers and intermediaries. For example, various auction methods are specified in Davis and Holt (Davis and Holt 1993) for finding prices. Price discovery mechanisms can also be biased to shift surplus from the trade to specific transaction stakeholders.

The processes specifying and coordinating the actual delivery of goods from the seller to buyer. Again, in a trade the direct costs of delivery may be assumed differently by different players.

These processes define the terms and methods of payment permitted and ensure the settlement of payments in the exchange. Third parties often provide the infrastructures for exchange.

This is a core set of activities used to verify the quality and features of the product offered, the authenticity of the trading parties, and monitor conformance to the contract or agreement among parties. Authentication may involve third parties who provide credit check, notarization, and other services to reduce the uncertainty of buyers and sellers.

Authenticating the quality of a product prior to purchase mitigates against adverse selection risks (Akerlof 1970, Kein et al. 1978). Monitoring processes in a complex transaction work to ensure that the trade is successfully completed and mitigate against moral hazard risks. Third parties to the transaction may play a critical role in monitoring transactions, ensuring nonrepudiation and completion of agreements. a lot he or she will purchase. The buyer provides the bid and, when the bid is accepted, the clock is reset and the process is re-started to clear the remaining inventory. The auctioneer may introduce a new minimum quantity to ensure the entire lot clears. Each clock can handle nearly 1,000 transactions an hour (approximately one transaction in four seconds). On average, 15 million flowers are traded daily at the VBA in 30,000 transactions.

We investigated the use of information technology in these auctions over the span of three years, collecting data through interviews with auction officials and participants and through review of all relevant published reports and archival material. Next we used the process categories identified in the previous section to organize the information and systematically evaluate or compare the impacts of specific IT innovations and process changes on different stakeholders in the DFA. This process-stakeholder analysis was used to identify changes in benefits and costs of different exchange processes, and the relative value of these innovations to different stakeholders. A case method was used because it enables rich data and "reality" to be captured in greater detail than other methods. The case method also permits us to consider a greater number of explanatory variables. We then undertook a cross-case analysis on multiple IT initiatives in the Dutch flower markets to generate propositions that explain the success or failure of specific innovations and more general impacts of new information technologies on markets. While we acknowledge that a single case cannot be generalized into a theory, a cross-case analysis is a useful step in theory construction by identifying patterns that provide testable propositions (Eisenhardt 1989, Yin 1981).

\subsection{An Evaluation of the Traditional Dutch Flower Auction}

Utilizing the previous process categories, Table 3 summarizes the key features, strengths, and weaknesses of the traditional Dutch flower auction. This provides a baseline for comparision and evaluation of process changes enabled by information technology. 
KAMBIL AND VAN HECK

Reengineering the Dutch Flower Auctions

Table 2 Description of Trade Context Processes

\begin{tabular}{ll} 
Process $\quad$ Description of Trade Context Processes \\
\hline
\end{tabular}

6. Communications and
Computing

7. Product Representation

8. Legitimation

9. Influence Structures and Processes

10. Dispute Resolution
Communications and computing processes underlie and bind all trading processes. New communications capabilities in terms of richer media, faster transfer speeds, improved ease of use and lower infrastructure costs transform coordination capabilities within and across trade processes. Similarly, improved processing, storage, input-output, and software technologies, further transform the coordination and decision making capabilities of stakeholders in each process. These transformations change the specific transaction costs and opportunity costs perceived by buyers, sellers, and intermediaries.

Product representation processes determine how the product attributes are specified to the buyer or other third parties. To what extent is there a standardized product and quality specification language? Both the buyers' and sellers' costs are reduced by informational standards or well-specified languages to represent the key quality, functional and aesthetic attributes of the product. If the product is well represented, the uncertainty of the buyer is lower. The costs and methods of implementing a uniform product representation scheme vary in different market mechanisms.

This process is used to validate the trade or exchange agreement. It defines how bids, or agreements are recognized as valid and binding commitments by exchange parties. In different trading situations, different procedures and rituals are undertaken to legitimate a transaction. Often this is done by announcing the agreement, and participants to the agreement, to a broader audience through a formal process.

These processes implement mechanisms to enforce obligations or penalties to reduce opportunism risks. Kambil (1992) defines two distinct influence processes developed from social exchange and transactions cost theories. These are: incentives and sanctions, and credible commitments. Incentives and sanctions include performance rewards for completing a contract on time, or penalties for misrepresenting products, or denial of access to an exchange network. A reputational system defines a special class of incentives and sanctions. Actions taken to enhance and create a good reputation serve to create trust in the party. When a social system establishes a reputation as a valued asset to sellers or buyers, opportunistic behaviour that can sully the reputation becomes more costly.

Investment in credible commitments (Williamson 1985) or asset-specialized investments by both exchange parties creates hostages such that the loss of the relationship will create a significant cost for both parties. This serves to signal commitment to the relationship by both parties and mitigates against opportunism risks. The types of commitments, the importance of reputation, and institutional authority to create incentives and sanctions can serve to reduce risks and the costs associated with other processes.

All exchanges occur in a broader legal or institutional context which provide various processes for resolving disputes among parties and structures decision rights in the event of conflict. Frms may elect to directly resolve disputes through negotiation, commit to third-party arbitration or court ordering of disputes. The latter is typically the most expensive alternative. Dispute-resolution processes adopted in an exchange relation, and the allocation of decision rights to structure solutions to disputes are crucial to reducing risks for buyers and sellers. Where goods are exchanged, disputes can be resolved by replacement of a defective product, and warranty mechanisms.
The Dutch flower auctions provide buyers and sellers with a highly efficient infrastructure to support exchange. As summarized in Table 3, they provide efficient search, communication, and product representation capabilities for highly varied products. The auctions are also very efficient in determining price, enabling approximately 1,000 transactions per clock per hour on a low-value good. The auction method eliminates problems of haggling and reduces bargaining costs that are otherwise associated with the trade of nonstandard and unusual-value products (Milgrom and Roberts 1990). By operating at a high clock speed, encouraging competition among buyers, and setting a fixed time by which to complete a transaction (or the clock goes to zero), the auction enables efficient trading. The hub and spoke operation and the logistics within the auction hall allow the timely transfer of a large volume of flowers from suppliers to buyers. By intermediating all buyer-grower exchanges, the auction also provides efficient quality control, settlement, 
KAMBIL AND VAN HECK

Reengineering the Dutch Flower Auctions

Table 3 Features of the Traditional Dutch Flower Auctions

\begin{tabular}{|c|c|c|c|}
\hline Exchange Process & Implementation & Strengths & Weaknesses \\
\hline 1. Search & $\begin{array}{l}\text { All trading opportunities are found at the } \\
\text { auctions. }\end{array}$ & $\begin{array}{l}\text { Search costs are reduced as the } \\
\text { centralized auction aggregates major } \\
\text { trading opportunities in one location. }\end{array}$ & $\begin{array}{l}\text { The buyers have to come to the auction } \\
\text { halls, and sellers have to deliver } \\
\text { products to the auction hall. }\end{array}$ \\
\hline 2. Valuation & The Dutch auction clock method. & $\begin{array}{l}\text { Very efficient for small lot trading. All } \\
\text { transactions occur in a fixed time slot } \\
\text { leading to } 1,000 \text { transactions per } \\
\text { hour. }\end{array}$ & $\begin{array}{l}\text { Auction prices for specific products } \\
\text { decrease during the day. To assure } \\
\text { fairness, assignment of auction } \\
\text { sequence for different growers is done } \\
\text { by lottery. Clock speeds and small lots } \\
\text { stretch the cognitive capabilities of } \\
\text { buyers favoring higher prices for } \\
\text { growers. }\end{array}$ \\
\hline 3. Logistics & $\begin{array}{l}\text { The auction facilities are a central hub } \\
\text { providing logistics support for } \\
\text { transferring products from sellers to } \\
\text { buyers. These costs are shared among } \\
\text { all buyers. }\end{array}$ & $\begin{array}{l}\text { Very efficient transfer of product from } \\
\text { seller to buyers. The centralized } \\
\text { auction trading allows specialization, } \\
\text { transportation, and other resources. }\end{array}$ & $\begin{array}{l}\text { Packaging costs are incurred multiple } \\
\text { times-for transport to and from the } \\
\text { auction. Multiple handling of flowers } \\
\text { can damage them. }\end{array}$ \\
\hline $\begin{array}{l}\text { 4. Payments and } \\
\text { Settlements }\end{array}$ & $\begin{array}{l}\text { The auctions provide systems for order } \\
\text { tracking, payments, and settlements } \\
\text { with efficient one-day settlement } \\
\text { periods. }\end{array}$ & $\begin{array}{l}\text { Shared costs among auction participants } \\
\text { and economies of scale in these } \\
\text { systems. }\end{array}$ & \\
\hline 5. Authentication & $\begin{array}{l}\text { The auction house authenticates } \\
\text { participants and grades the quality of } \\
\text { the products. It is also responsible for } \\
\text { tracking and ensuring delivery of } \\
\text { orders to buyers. }\end{array}$ & $\begin{array}{l}\text { Very efficient for large numbers trading. } \\
\text { The auction reduces counter-party } \\
\text { risks, product, and related } \\
\text { authentication costs for buyers and } \\
\text { sellers. }\end{array}$ & $\begin{array}{l}\text { Buyers and growers perceive quality } \\
\text { grades as too broad, artificially } \\
\text { inflating valuation of products at the } \\
\text { lower end of quality rating. }\end{array}$ \\
\hline $\begin{array}{l}\text { 6. Communication and } \\
\text { Computing }\end{array}$ & $\begin{array}{l}\text { Simple visual communications of } \\
\text { competitors, product, price, and other } \\
\text { trading information on the clock. A } \\
\text { simple computerized system for } \\
\text { communicating bids. }\end{array}$ & $\begin{array}{l}\text { Efficient and low costs for shared } \\
\text { communications infrastructure. }\end{array}$ & $\begin{array}{l}\text { Requires synchronous communications } \\
\text { for trading, and colocation of parties } \\
\text { to the limited trading floor. Growers } \\
\text { do not know final demand patterns for } \\
\text { products. }\end{array}$ \\
\hline $\begin{array}{l}\text { 7. Product } \\
\text { Representation }\end{array}$ & $\begin{array}{l}\text { The product is represented by itself, and } \\
\text { simple codes identifying grower and a } \\
\text { gross level quality grade. }\end{array}$ & $\begin{array}{l}\text { Buyers can directly inspect the product } \\
\text { in the auction hall if they want to do } \\
\text { so. }\end{array}$ & $\begin{array}{l}\text { Buyers and growers perceive quality } \\
\text { grades as too broad. The cost of } \\
\text { visual inspection. }\end{array}$ \\
\hline 8. Legitimation & $\begin{array}{l}\text { The auction intermediary is responsible } \\
\text { for recording bids and legitimating } \\
\text { transactions. }\end{array}$ & & \\
\hline 9. Influence & $\begin{array}{l}\text { The auctions can exclude growers or } \\
\text { buyers who do not meet various } \\
\text { criteria. }\end{array}$ & $\begin{array}{l}\text { The auctions, by centralizing and } \\
\text { requiring the product to be delivered } \\
\text { prior to sale, minimizes opportunism } \\
\text { risks. }\end{array}$ & Auction rules tend to favor the growers. \\
\hline 10. Dispute Resolution & $\begin{array}{l}\text { The auctions provide for various } \\
\text { arbitration mechanisms and rules for } \\
\text { resolving problems. This reduces } \\
\text { dispute resolution costs. }\end{array}$ & & \\
\hline
\end{tabular}


and dispute resolution mechanisms that mitigate against opportunism risks encountered by buyers and sellers. These features reduce transaction costs to growers and buyers.

However, as summarized in Table 3, there are disadvantages of this specific model of trading. First, buyers must be physically present at the correct location and correct time to bid on a specific product. In addition, it is hard to simultaneously search other markets to estimate prices. Today, large buying organizations provide cellular phones to their buyers to coordinate purchases across auctions. In response, the auctions are beginning to coordinate trading similar products at the same times in different auction houses. This will allow the large buyers to find the best price across auctions. The auction structure also inhibits growers from understanding the true preferences of buyers, as growers are separated from the sale of their produce by the auction.

Other disadvantages for specific stakeholders are understood when we consider the auction's ownership and incentive structure. A number of auction rules favor growers, who are the auction owners, over buyers. First, the clocks move at a high speed. Higher speeds reduce the decision time available to buyers. This results in higher bid prices. The auctions have experimented with different clock speeds and it is widely known that faster clock speeds result in higher prices. However, the auctions are unwilling to fully disclose the results of their experiments and selection of auction clock speeds. Second, the auction rules and service costs to buyers for processing trades favors trading in smaller lots instead of purchases of large lots. This ensures that no one party can purchase the entire lot without competition. It also increases the cognitive complexity and competition confronted by buyers. Buyers must now purchase products and adjust purchasing decisions to availability across multiple clock auctions. This imperfect information and low transparency about available inventories favors growers, although more empirical work needs to be done to discover the magnitude of the growers' advantage.

\subsection{Challenges to the Traditional Dutch Auctions}

In the early 1990s the Dutch flower industry and auctions faced a number of challenges. First, rapid growth in the flower industry created increasing demands for logistics support, space in the auctions and complaints about nearby traffic congestion. As the two major auctions were close to their limits in terms of complexity, capacity, and room to expand, increases in capacity would require changes in auction logistics or investment in new facilities. A second problem confronted by the industry was the consolidation of buyers into larger entities. Buyers for supermarkets and large retail store chains wanted to purchase larger lot sizes and coordinate purchases across different markets to take advantage of the best price. Some large retailers, like Marks and Spencer, were bypassing the Dutch auctions and their commissions to source directly from growers in Spain and other countries. Third, the success of the Dutch auctions as the world's leading flower auctions and entry point into downtream logistics and distribution led to an increased flow of foreign cut flowers to the Dutch flower auctions. In 1994, 15\% of flowers traded at the largest Dutch Flower auctions were imported from and re-exported to foreign countries (sometimes back to the country of origin). This increased foreign competition to Dutch growers, and in 1993 the import of foreign rose stems to the two largest auctions reduced average prices by $40 \%$ during the winter season. Subsequently, the Dutch grower cooperatives voted to limit foreign access to the major auctions in 1994. These challenges led to a number of successful and unsuccessful information technologyenabled transformations of trading in the industry. These initiatives are critically examined below, using a process-stakeholder analysis, to illustrate major process changes and benefits or costs of the initiatives to different stakeholders.

\section{IT-Enabled Dutch Auction Transformations: A Process- Stakeholder Analysis}

Four major information technology-enabled initiatives were undertaken to transform the Dutch flower auctions and respond to the above challenges. Two unsuccessful initiatives were the BVH's Holland Vidifleur system and the VBA's Sample-Based Auction (SBA) system. These initiatives promised to simplify 
auction hall logistics and add extra transaction capacity to the auction. Two successful initiatives were the Holland Supply Bank (HSB) system and the Tele Flower Auction System (TFA). The former system responded to the need of large buyers, and the latter provided a new auction for foreign produce. While the auctions have used information technology extensively to support order processing, inventory, and logistics, they primarily supported or automated existing auction processes having impacts typically limited to the auction intermediary (Van Heck and Groen 1994). The IT-enabled initiatives discussed below fundamentally changed the implementation or conduct of one or more specific auction processes, and the way in which buyers, auctions, and sellers interact. Summary information on the initiatives is given in the Table 4.

\subsection{The Vidifleur Initiative}

The BVH auction implemented the Vidifleur initiative in response to the growing capacity and logistics requirements of the auction. Vidifleur intended to use video auctioning to decouple the price determination and logistics mechanisms and to allow buyers to trade from outside the auction hall. When the product arrived at the auction a picture was taken, digitized, and stored in auction computers. These computers transferred the picture for display to a screen in the auction hall, where buyers could bid for the product based on the image of the product. Buyers were also able to bid for and look at the flowers on computer screens in their private auction offices. The computers in the private office provided a screen-based representation of the clock which was synchronized with the clock in the auction hall.

The Vidifleur experiment initiated by the BVH information technology staff (Spooner and Copeland, 1992), ${ }^{2}$ was implemented with minimal changes to the original auction clock process. Experimenters converted one of three auction clocks in a room to have video screens for product display around the clock. The auction also moved the real product under the auction clock, providing a second visual display of the product. An auction room solely dedicated to this experiment was unavailable because of the demand for limited auction facilities, and altering existing logistics processes was deemed too expensive for the experiment.

Auctioneers expected this remote video auctioning to provide buyers with better information, as they could work from the comfort of their own offices and also access their office computers for purchasing, order, sales, and local inventory information. The auctioneers also knew that buyers often tended to select goods from specific sets of growers rather than inspect the product in great detail and expand the selection of producers. This buyer behaviour suggested that grower reputations played a substantial role in shaping purchases, and that the visual inspection of flowers

\footnotetext{
${ }^{2}$ Spooner and Copeland (1992) provide a teaching case of IT initiatives at BVH (previously called Flower Auction Westland) in which they discuss the motivation and technology used to implement the Vidifleur experiment.
}

\begin{tabular}{|c|c|c|c|c|c|}
\hline & Traditional DFA & Holland Vidifleur System & VBA Sample Based Auction & Holland Supply Bank & Tele Hower Auction System \\
\hline Start (End) Year & 1890 & 1991 (1991) & 1994 (1994) & 1993 & 1993 \\
\hline Product & $\begin{array}{l}\text { Howers and } \\
\text { Potted Plants }\end{array}$ & Potted Plants & Potted Plants & $\begin{array}{l}\text { Howers and Potted } \\
\text { Plants }\end{array}$ & Howers \\
\hline Sellers & Growers & Growers & Growers & Growers & Growers \\
\hline Intermediary & Hower Auctions & $\begin{array}{l}\text { Hower Auction Holland } \\
\text { (BVH) }\end{array}$ & $\begin{array}{l}\text { Hower Auction Aalsmeer } \\
\text { (VBA) }\end{array}$ & $\begin{array}{l}\text { Hower Auction } \\
\text { Holland (BVH) }\end{array}$ & East African Howers (EAF) \\
\hline Buyers & Wholesalers & Wholesalers & Wholesalers & Wholesalers & Wholesalers \\
\hline Valuation & $\begin{array}{l}\text { Dutch Auction } \\
\text { Cock }\end{array}$ & Dutch Auction Clock & Dutch Auction Clock & $\begin{array}{l}\text { Negotiated Posted } \\
\text { Offer }\end{array}$ & Dutch Auction Clock \\
\hline
\end{tabular}


prior to purchase was less important to the process. Despite these expectations, buyer reaction to screenbased trading was negative and led to the termination of the experiment in late 1991. Table 5 summarizes the areas of key process changes, benefit expectations and actual results of the initiative. We focus only on buyers and the auction intermediary, as no major process changes occur for sellers.

As highlighted in Table 5, buyers cited three main reasons for not adopting the new system. First, the clock-based trading system provided no new efficiencies for buyers. Second, the quality of the auction hall video display was perceived as poor, and trading from outside the auction hall created an informational disadvantage. In floor-based trading the buyers could observe each other, and the reactions of other major buyers (from supermarket chains, etc.) to specific bids. This important nonprice information was incorporated into the decision making of the buyers. Video-based auctioning on a computer was a limiting medium, not rich enough to capture this information. Thus buyers had limited advantage in trading from their offices, when there was also a floor-based auction which provided the traders with more information. Indeed, buyers who tried to trade from offices complained that they could not feel the "tension" in the marketplace. Third, at the back of each auction hall is a coffee shop where buyers interact informally and share information about the market. Again, access to the social interaction and information was more difficult through screen-based trading.

\subsection{The Aalsmeer Sample-Based Auction}

In contrast to the BVH, the Aalsmeer auction began a sample-based auction for trading potted plants (Griffioen 1994a, 1994b; Van Heck and Groen 1994). In

Table 5 Process-Stakeholder Impacts of Vidifleur

\begin{tabular}{|c|c|c|}
\hline Exchange Process & Auction Intermediary & Buyer \\
\hline 1. Search & No change. & No change. \\
\hline 2. Valuation & No change. & No change. \\
\hline 3. Logistics & $\begin{array}{l}\text { Expected: Auction hall logistics would be eliminated } \\
\text { allowing for cheaper and more frequent transactions } \\
\text { and new space for clocks. } \\
\text { Actual: No change during the experiment due to } \\
\text { potential disruptions to the current process. Real } \\
\text { product appeared in the hall synchronized to clock. }\end{array}$ & No change. \\
\hline 4. Payments and Settlements & No change. & No change. \\
\hline 5. Authentication & No change in the quality grading process. & $\begin{array}{l}\text { In a full-scale system, buyers would find it harder to } \\
\text { visually inspect and authenticate quality. }\end{array}$ \\
\hline 6. Communication and Computing & $\begin{array}{l}\text { Shift to electronic communications. Eectronic } \\
\text { representation of the clock as well as the product. }\end{array}$ & $\begin{array}{l}\text { Expected: Eectronic communications could substitute } \\
\text { for buyer presence in the auction halls. } \\
\text { Reality: Eectronic communications does not capture } \\
\text { nonprice information, such as other bidders' } \\
\text { expressions and reactions to specific bids. It } \\
\text { reduces social interaction opportunities. }\end{array}$ \\
\hline 7. Product Representation & $\begin{array}{l}\text { Expected: Bectronic flower clock and video } \\
\text { representation of flowers would not adversely affect } \\
\text { the sale. } \\
\text { Result: Negative buyer reaction to video quality. }\end{array}$ & $\begin{array}{l}\text { Expected: Buyers would make decisions from their } \\
\text { offices using computers rather than the auction } \\
\text { hall. } \\
\text { Result: Negative reaction. Buyer perceive the video } \\
\text { quality as poor. }\end{array}$ \\
\hline 8. Legitimation & No change. & No change. \\
\hline 9. Influence & No change. & No change. \\
\hline 10. Dispute Resolution & No change. & No change. \\
\hline Net Benefits & None. & Negative. \\
\hline
\end{tabular}


this model, growers send a sample of the product to the auction house along with information on available inventory. During the auction the sample represents the entire inventory available to buyers who can bid for the product and specify product packaging and delivery requirements. Growers then package the product as specified and deliver it the next day to the buyer location in the auction complex or to other buyer warehouses. Growers, buyers and auctions used electronic data interchange to share all the information required in this process. ${ }^{3}$ This trading model reduces the number of times a product is handled, reducing overall packaging costs and damage.

The different actors-the auctions, growers, and buyers-expected a number of different benefits. First, by uncoupling logistics and price determination, the auctions and growers expected the number of transactions per hour to increase. In reality the number of transactions per hour decreased, as buyers had to specify terms of delivery. Second, while the auctions expected $45 \%$ of the supply of potted plants to be transacted in the sample-based auction, only $10 \%$ of the product was transacted this way. Thus, sample-based auctions also did not effectively reduce storage requirements at the auction. After numerous attempts to increase the volume of sample-based auctions, they were discontinued in late 1994. Table 6 summarizes results of the initiative. Only areas of change are discussed below.

The sample-based auction failed to meet expectations for many reasons. First, the incentives and benefits to buyers and growers (in particular) did not change substantially to encourage their participation in this market. Specifically, growers received no extra compensation for modifying packaging and delivery practices to suit the customer. Second, the growers perceived that they got lower prices in a slower auction. To overcome this disadvantage growers would break the same product into different sample lots so that it

\footnotetext{
${ }^{3}$ Beginning in 1992, growers and auctions adopted electronic data interchange to communicate product, order, and transaction information to each other. EDI reduces double entry of data into systems and paperwork, and reduces errors. Growers who use EDI can submit data on shipments until 3:00 p.m. instead of 12:00 p.m. for paper transfer.
}

would be priced multiple times during the auction, hoping it would lead to higher prices. Third, the auction rules initially did not provide incentives to buyers by supporting transactions on large lots. Instead, the auction maintained rules to favor transactions in small lots. Thus, an insufficient number of buyers and sellers initially adopted this new form of trading (Van Heck and Ribbers 1996).

In response to this failure, the auction undertook various rule changes beginning in March 1994. First, the auction established a price floor of $70 \%$ of average price of a flower type in the most recent five days to reduce volatility and downside risks. Second, the representative lot was auctioned first. This sample lot typically received a higher price than following lots of the same type and quality. Buyers believed the first sample to always be of best quality within any quality rating. Third, the lot size was increased to three stapelwagens ${ }^{4}$ from one. The growers were also forced to increase the number of plants offered in any one transaction, so that they did not game the system. To meet the needs of large buyers, buyers were permitted to buy either one or three stapelwagens per transaction. To prevent gaming, the grower for any type of flower was only allowed one auction per category of product for price determination. These rule changes temporarily stabilized the market, but the lack of growers and buyers adopting the method led to its demise in late 1994.

\subsection{The Holland Supply Bank: Image Representations and Negotiated Trading}

To respond to the needs of larger buyers, the BVH and Aalsmeer auctions have diversified to create a brokered market for flowers and potted plants. In the "bemiddelingsbureau" (BB), or Mediation Office, an auction employee acts as an agent for the growers and negotiates between growers and buyers in a forward market. Prices, product specifications, amount of lots, and delivery specifications are specified in a contract which is legitimized and monitored by the mediation office. In 1994, about 18\% of flowers and potted plants were traded this way. In 1996, this amount increased to $22 \%$. The mediation office is useful for the sale of

\footnotetext{
${ }^{4}$ Stapelwagens are a fixed-size cart used to transport flowers through the auction complex.
} 


\begin{tabular}{|c|c|c|c|}
\hline Exchange Process & Growers & Auctions & Buyers \\
\hline 1. Search & No change. & No change. & No change. \\
\hline 2. Valuation & $\begin{array}{l}\text { Expected no change. } \\
\text { Result: Cassify into smaller lot sizes } \\
\text { so same product is sampled and } \\
\text { effectively priced multiple times. } \\
\text { Price is on average } 10 \% \text { less on } \\
\text { remainder than sample lot. This } \\
\text { results in less revenue. }\end{array}$ & $\begin{array}{l}\text { Expected no change. } \\
\text { Auction process is slowed down due } \\
\text { to the need to specify packing } \\
\text { information and buyer gaming. } \\
\text { Lower commissions on remainder for } \\
\text { sample lot. } \\
70 \% \text { of previous five days' average } \\
\text { price as a price floor. }\end{array}$ & $\begin{array}{l}\text { Greater uncertainty about product } \\
\text { quality leads to discounting of } \\
\text { nonsample lots. }\end{array}$ \\
\hline 3. Logistics & $\begin{array}{l}\text { Increased burden from needing to } \\
\text { customize packaging to buyer } \\
\text { specifications. }\end{array}$ & Lower logistics costs. & More efficient delivery of the product. \\
\hline 4. Payments and Settlements & No change. & No change. & No change. \\
\hline 5. Authentication & No change. & $\begin{array}{l}\text { Minor change ensuring product is } \\
\text { properly delivered. }\end{array}$ & $\begin{array}{l}\text { Inability to authenticate quality ahead } \\
\text { of time. Must verify product is } \\
\text { properly received. }\end{array}$ \\
\hline 6. Communication and Computing & $\begin{array}{l}\text { Minor change: More use of } \mathrm{EDI} \text { to } \\
\text { send coordination information. }\end{array}$ & $\begin{array}{l}\text { Minor change: More use of } \mathrm{DI} \text { to } \\
\text { send coordination information. }\end{array}$ & $\begin{array}{l}\text { Minor change: More use of } \mathrm{DI} \text { to } \\
\text { send coordination information. }\end{array}$ \\
\hline 7. Product Representation & $\begin{array}{l}\text { Enabled to select a sample lot that is } \\
\text { of higher quality than the } \\
\text { remaining product. }\end{array}$ & $\begin{array}{l}\text { Sample lot substitutes for actual } \\
\text { transaction lot. }\end{array}$ & $\begin{array}{l}\text { Buyers cannot visually evaluate the } \\
\text { whole offer. } \\
\text { Must decide to buy based on the } \\
\text { sample lot. }\end{array}$ \\
\hline 8. Legitimation & No change. & No change. & No change. \\
\hline 9. Influence & $\begin{array}{l}\text { More difficult due to more complex } \\
\text { transaction. }\end{array}$ & No change. & No change. \\
\hline 10. Dispute Resolution & No change. & No change. & No change. \\
\hline Net Benefits & Negative. & Negative. & Negative. \\
\hline
\end{tabular}

large lots to large buyers, like supermarkets, for the occasions market.

The mediation office, as an honest broker, reduces the costs of search, communications, and bargaining for buyers and sellers. It also provides a mechanism to legitimate the transaction and resolve disputes in the event the contract is not met. Image databases of product types and inventory are especially useful for transactions in the mediation office. Wholesale buyers find that the pictures of the product are also very useful marketing tools to downstream retailers. Electronic data interchange is used for communications of orders and the coordination of settlements, and delivery. This results in fewer errors and greater transaction efficiency.

Table 7 summarizes the major impacts of the Holland Supply Bank on different stakeholders.

\subsection{The Tele Flower Auction System}

Since 1993, the Dutch flower industry has been concerned about the increasing flow of foreign flower products into the Dutch flower auctions and downstream logistics and distribution systems. These imports were having an adverse effect on the margins of Dutch growers and the prices of key commodity products like roses and carnations. After a referendum in September 1994, the growers, who are the owners of the Dutch auctions, decided to ban foreign grower participation in the auctions during the summer. These efforts to reduce foreign access to the traditional Dutch auctions led buyer organizations and foreign growers to announce the creation of competing auctions. In particular, the East African Flower (EAF) importers association responded to this ban by developing the Tele Flower Auction (TFA) (Van Heck et al. 1997). 
Table 7 Process-Stakeholder Impacts of the Holland Supply Bank

\begin{tabular}{|c|c|c|c|}
\hline Exchange Process & Growers & Auctions & Buyers \\
\hline 1. Search & $\begin{array}{l}\text { Benefit: The HSB permits growers to } \\
\text { search for buyers. }\end{array}$ & $\begin{array}{l}\text { Benefit: Efficient image database } \\
\text { combined with broker matching } \\
\text { system. }\end{array}$ & $\begin{array}{l}\text { Benefit: Large buyers' search costs } \\
\text { are reduced. }\end{array}$ \\
\hline 2. Valuation & $\begin{array}{l}\text { Expected no change. } \\
\text { Benefit: Slightly higher prices with } \\
\text { less uncertainty. }\end{array}$ & $\begin{array}{l}\text { Mediation process is less costly than } \\
\text { logistics-intensive process. }\end{array}$ & $\begin{array}{l}\text { Cost: Slightly higher prices but } \\
\text { reduced uncertainty. }\end{array}$ \\
\hline 3. Logistics & $\begin{array}{l}\text { Benefit: Efficient product transfer in } \\
\text { bulk to buyer. }\end{array}$ & $\begin{array}{l}\text { Benefits: Less logistics in the auction } \\
\text { hall. }\end{array}$ & $\begin{array}{l}\text { Benefits: Direct delivery from seller } \\
\text { with no repacking costs. }\end{array}$ \\
\hline 4. Payments and Settlements & As specified in the contract. & Managed by mediation office. & As specified in the contract. \\
\hline 5. Authentication & No change. & $\begin{array}{l}\text { Costs: Quality managers evaluate } \\
\text { sample, and assign a quality } \\
\text { grade. Monitor and ensure } \\
\text { delivery. }\end{array}$ & $\begin{array}{l}\text { Cost: Inability to authenticate quality } \\
\text { ahead of time. }\end{array}$ \\
\hline 6. Communication and Computing & $\begin{array}{l}\text { Minor change: More use of } \mathrm{EDI} \text { to } \\
\text { send coordination information. }\end{array}$ & $\begin{array}{l}\text { Minor change: More use of } \mathrm{BI} \text { to } \\
\text { send coordination information. }\end{array}$ & $\begin{array}{l}\text { Minor change: More use of } \mathrm{El} \text { to } \\
\text { send coordination information. }\end{array}$ \\
\hline 7. Product Representation & $\begin{array}{l}\text { Cost: Growers send data and sample } \\
\text { lot. Growers perceive quality } \\
\text { grades as broad and don't reflect } \\
\text { true quality. }\end{array}$ & $\begin{array}{l}\text { Cost: Quality managers create a } \\
\text { digital image of sample lot to } \\
\text { present to buyers in addition to } \\
\text { the rating. }\end{array}$ & $\begin{array}{l}\text { Cost: Buyers cannot visually evaluate } \\
\text { the offer and perceive quality } \\
\text { grades are broad. Benefit: } \\
\text { However, images are useful for } \\
\text { downstream trade. }\end{array}$ \\
\hline 8. Legitimation & No change. & Mediation office. & No change. \\
\hline 9. Influence & No change. & No change. & No change. \\
\hline 10. Dispute Resolution & No change. & Mediation office. & No change. \\
\hline Net Benefit & $\begin{array}{l}\text { Positive - higher prices and less } \\
\text { uncertainty. }\end{array}$ & Positive—less logistics requirements. & $\begin{array}{l}\text { Positive-ability to transact for large } \\
\text { lots into the future. }\end{array}$ \\
\hline
\end{tabular}

TFA is a completely electronic auction that enables buyers to trade at a distance. Decoupling the logistics and price discovery processes, the buyers can bid for different flowers via their personal computer (PC) screens (Bos 1995, 1996; Eras 1995; Van Vliet 1994). Using ISDN services of the Dutch PTT, each buyer's PC is connected from his or her office to a fully computerized Dutch auction clock. The PC provides information on the producer, product, unit of currency, quality, and minimum purchase quantity. For added convenience, the PC also provides the buyer with textual information on the available flowers, specific lots for sale, and two digital images of each lot. One image gives an overview of the lot to inspect ripeness of flowers, and the other presents details of the flower bud, to evaluate its size and diagnose potential diseases. The buyer can then use the PC's custom software to flag interesting lots, so that the computer can alert the buyer when it is time to auction the specific lot. On the
PC screen the buyer sees the Dutch auction clock. The clock hand starts at a high price and drops until a buyer stops the clock by pushing the space bar at the keyboard of the PC. The auctioneer then asks the buyer via an open telephone connection how many flowers of the lot he or she will buy. When the buyer provides the amount, the auctioneer legitimates the transaction. The clock is then reset, and the process begins for the next lot until the remainder of the product is sold.

The auction logistics are substantially simpler than the traditional DFA. The EAF receives and stores flowers and plants from growers in a distribution warehouse facility in the nearby town of Amstelveen. The flowers from the Amstelveen facility are transported to the wholesaler's address directly by transporters of EAF. In an agreement with the VBA, the EAF was also permitted to deliver products to the buyer's rented facilities at the VBA. This way the auction minimizes most internal logistics operations and is able to deliver 
flowers to buyers in a timely way. The major process changes relative to the traditional Dutch auction are summarized in Table 8.

Overall, TFA was an immediate success. Since its implementation in March 1995, it has grown from auctioning the product of 2 main East African growers to include products from 40 growers in Africa, Spain, Colombia, France, India, and Israel. By the end of the year, the TFA had nearly 160 buyers (about half are located in the Aalsmeer area; the rest are scattered throughout the Netherlands). The TFA was estimated to be the fourth largest flower auction in Holland by the end of 1996.

Why were buyers willing to accept this new auction? First, it uniquely satisfied the buyers' needs to inexpensively purchase foreign flowers and include them in their existing distribution chains. Second, buyers we interviewed said the flowers they purchased from the TFA often exceeded their quality expectations as determined by the quality grades. Thus, the TFA created a reputation for setting high quality standards, enhancing trust in the auction and minimizing adverse selection. If necessary buyers close to the warehouse location could physically inspect the product. Buyers were also impressed with the computer data, the quality of the products, and the speed of delivery after their purchases were completed. The buyers also felt they had a better overview of the auction, as compared with the traditional Dutch auction.

\section{Lessons Learned from IT- Innovations in the Dutch Flower Auctions}

Based on our research we did a cross-case analysis to identify factors that influence the successful or unsuccessful use of information technology in markets. We use this analysis to develop a series of observations on the market impacts of IT as well as the success and failure of IT-based initiatives in markets. These observations stated as propositions, and the supporting analysis and discussion are given below.

Proposition 1. The application of information technologies to trading can enable increased efficiency and separation of informational and physical trading processes. This in turn will permit more varied forms of trading, customized to different user requirements.

The four cases illustrate the use of information technology to separate the informational and physical trading processes. In all cases the valuation and logistic processes are increasingly de-coupled from one another in time and space. For example, the Holland Supply Bank illustrates the implementation of the mediation bureau to broker trading of large futures contracts between large buyers and different growers separating logistics and information processes. Similarily, in the Tele Flower auction, the buyers are able to bid for products from remote locations. The buyers can customize the system by specifying preferences and receiving alerts when the product they want is being auctioned.

These observations also lend support to Malone et al. (1987), who note that information technology enables personalized markets where software agents would support trading customized to individuals and firm preferences. While the new flower auctions are not as fully advanced, they achieve a better fit between the transaction preferences of larger buyers and the organization of exchange processes by overcoming the capacity limits and colocation requirements for floorbased trading. These new trading mechanisms better suit the unique requirements of large versus small buyers.

The observations across cases illustrate that information technology substantially reduces coordination costs and enhance communications capabilities. These changes allow transacting parties to separate in space (e.g., TFA bidding process) and time (e.g., HSB delivery logistics) the informational and physical components of trading processes. Indeed, the informational and physical components within each of the ten exchange processes defined in this paper could be decoupled from one another and provided by different actors without the necessity for colocation. Over time this will permit the creation of more distributed and customized market institutions for the trade of physical goods.

Proposition 2. Information technology-enabled process innovations change the information available to different stakeholders. When different stakeholders perceive these 


\begin{tabular}{|c|c|c|c|}
\hline Exchange Process & Growers & Auctions & Buyers \\
\hline 1. Search & No change from DFA. & $\begin{array}{l}\text { Benefit: Efficient databases and } \\
\text { online system for presenting trade } \\
\text { opportunities. }\end{array}$ & $\begin{array}{l}\text { Benefit: Up-to-date online database } \\
\text { reduces search costs for specific } \\
\text { products. Alerts inform buyers of } \\
\text { opportunities. }\end{array}$ \\
\hline 2. Valuation & No change. & $\begin{array}{l}\text { Very efficient screen-based auction } \\
\text { clock process. }\end{array}$ & $\begin{array}{l}\text { Benefit: Screen trading enables better } \\
\text { oversight and concentration on } \\
\text { bidding. }\end{array}$ \\
\hline 3. Logistics & $\begin{array}{l}\text { Benefit: Efficient product transfer to } \\
\text { Amstelveen warehouses. }\end{array}$ & $\begin{array}{l}\text { Benefits: No auction hall logistics are } \\
\text { necessary. Less errors due to } \\
\text { simplicity of a decoupled system. } \\
\text { Cost: Transport to buyer locations. }\end{array}$ & $\begin{array}{l}\text { Benefits: Faster delivery from auction } \\
\text { due to decoupling of logistics and } \\
\text { price discovery. }\end{array}$ \\
\hline 4. Payments and Settlements & $\begin{array}{l}\text { 24-hour payment and settlement } \\
\text { clearing. }\end{array}$ & Managed by EAF. & $\begin{array}{l}\text { 24-hour payment and settlement } \\
\text { clearing. }\end{array}$ \\
\hline 5. Authentication & No change. & $\begin{array}{l}\text { Costs: quality managers evaluate } \\
\text { sample, and assign a strict quality } \\
\text { grade. Monitor and ensure } \\
\text { delivery. }\end{array}$ & $\begin{array}{l}\text { Benefit: Auction quality control } \\
\text { reduces risks-may exceed buyer } \\
\text { expectations. Cost: Inability to } \\
\text { authenticate quality ahead of time. }\end{array}$ \\
\hline 6. Communication and Computing & $\begin{array}{l}\text { Simplified phone and data } \\
\text { communications. }\end{array}$ & $\begin{array}{l}\text { Simplified phone and data } \\
\text { communications. }\end{array}$ & $\begin{array}{l}\text { Text representations and digital } \\
\text { images enable simplified } \\
\text { communications. }\end{array}$ \\
\hline 7. Product Representation & $\begin{array}{l}\text { Cost: Growers perceive quality } \\
\text { grades as broad and don't reflect } \\
\text { true quality. }\end{array}$ & $\begin{array}{l}\text { Cost: Text representation of product } \\
\text { in addition to the quality rating. }\end{array}$ & $\begin{array}{l}\text { Cost: Buyers cannot directly evaluate } \\
\text { the offered product. Benefits: } \\
\text { Screen-based representations } \\
\text { enable remote trading. }\end{array}$ \\
\hline 8. Legitimation & $\begin{array}{l}\text { Benefit: Growers don't have to be an } \\
\text { EAF member, enabling foreign } \\
\text { imports. }\end{array}$ & EAF is primary authority. & No change. \\
\hline 9. Influence & $\begin{array}{l}\text { Growers have little influence on } \\
\text { auction policies. }\end{array}$ & $\begin{array}{l}\text { EAF organization defines the market } \\
\text { rules. }\end{array}$ & $\begin{array}{l}\text { Buyers do not have direct influence } \\
\text { on auction rules. }\end{array}$ \\
\hline 10. Dispute Resolution & No change. & $\begin{array}{l}\text { No change: Arbitration by the auction } \\
\text { reduces costs. }\end{array}$ & No change. \\
\hline Net Benefit & $\begin{array}{l}\text { Positive: for excluded foreign } \\
\text { growers. }\end{array}$ & Positive: lower cost auction model. & $\begin{array}{l}\text { Positive: product access and remote } \\
\text { buying. }\end{array}$ \\
\hline
\end{tabular}

changes reduce the relevant information or trust, they will act to either increase the information available or discount prices to account for increased risks.

Market organizations, like other governance systems, are information processing systems that represent a consensus among different competing stakeholders on organizing the interdependent processes identified in $\S 2$. These processes serve to generate or organize information, or to reduce uncertainties and mitigate opportunism risks faced by different stakeholders (Kambil 1992). The prior literature on markets and technology generally presumes that information technology applications enable the provision of more relevant information to decision makers (Bakos 1991b, Brynjolfsson et al. 1994, Gurbaxani and Whang 1991, Malone et al. 1987). However, the cases above illustrate that IT can actually reduce the relevant information available to decision makers. The application of information technology to communication and product representation processes had major impacts on relevant information available for price discovery, authentication, and logistics processes. When information or trust as perceived by specific stakeholders was reduced in these processes, they or other interested stakeholders 
acted to increase the information and trust, or reduced prices to discount for new risks.

For example, in the SBA, the buyers chose to discount the prices bid for non-sample lots by nearly $10 \%$ because they could no longer authenticate quality by visual inspection. Similarily, growers in the SBA decreased lot sizes or reclassified their product so that the same product was displayed multiple times. The growers' objective was to have multiple new bidding cycles for price determination, hoping that multiple bidding competitions for smaller lots among buyers would generate new demand information leading to higher prices. Both of these responses reduced the attractiveness and efficiency of the sample-based auction, leading to its ultimate demise.

While the Holland Supply Bank and the Tele Flower auction reduced the ability of real-time authentication of the product, they provided new benefits to the different stakeholders or created trust in new ways. In the former, parties were able to trade in a way that reduced uncertainty and generated information about future availability of demand, prices and goods. In the latter, to create trust among buyers in the new auction process and establish a reputation for quality, the Tele Flower auction ensured that the product matched or exceeded buyers' expectations given a specific quality rating. While we cannot establish that the product was traded at a lower price than when it was visually inspected, the tight quality control that assures a product matches or exceeds its quality ratings leaves it open to being discounted to the price level of the quality rating rather than the price of the flower given perfect quality information.

The above observations are consistent with prior research on the governance of exchange relations. First, the need for information seeking to reduce uncertainty is well known. The generation of trust (the expectation of future nonopportunistic behavior) and preservation of good reputations is also important to reduce transaction costs or "friction" in exchange (Arrow 1974, Fukuyama 1995). Third, social exchange theorists have identified the importance of equity and fairness (Blau 1964, Homans 1961). The cases illustrate that reductions in information available due to an IT-enabled process discontinuity creates new information seeking or trust-generation costs. Market designers can respond to these requirements by allowing more information gathering by different stakeholders (buyers and sellers) or create trust and reputations for fairness. Both these choices lead to differential levels and allocations of costs across stakeholders. These costs and their distribution across stakeholders must be considered by designers of new IT-enabled market mechanisms if the new market is to be adopted.

Proposition 3. Market organizations are the meeting point for multiple stakeholders: buyers, sellers, and intermediaries with conflicting incentives. Given existing or competing market alternatives, no new IT-based initiative is likely to succeed if any key stakeholder is worse off after the IT- enabled innovation.

The process-stakeholder analysis framework developed in $\S 2$ of this paper was applied to map process changes and their impacts on different stakeholders. In the two cases of failure, the application of the framework clearly identified either the grower or the buyer was worse off from the innovation. For example, in the SBA the grower incurred new packaging costs and logistics costs. In the Vidifleur auction, the buyers did not perceive a new benefit from the system. The video quality was poor, authentication of quality less convenient, and trading online did not provide all the information available in the auction hall.

In contrast, the Holland Supply Bank and the Tele Flower auctions created new advantages for all stakeholders who participated. In the Holland Supply Bank, buyers were able to order large quantities of product and specify a contract for delivery on a future date, reducing the growers' uncertainty about future price levels. The Tele Flower auctions provided Dutch buyers with a source of foreign flowers, foreign growers with a trading location that could take advantage of the Dutch wholesaler's demand for flowers, and downstream logistics facilities.

These cases illustrate the need to carefully design and implement electronic markets and to include adequate incentives to different stakeholders for participation. All stakeholders must be better off with the new system rather than the old system, otherwise the new market will fail and revert back to the prior system if this alternative remains available. The processstakeholder analysis framework can be used by market designers to evaluate the consequences of their designs 
on processes and stakeholders to fulfill the above conditions.

Proposition 4. Biases in trading will depend on the ownership of the market and the availability of cost-effective trading alternatives. As owners of existing markets may not benefit from electronic trading, this incentive incompatibility will impede the transition to new electronic markets. A solution to this problem is to change market ownership or create new sources of competition.

Why did the traditional Dutch markets fail to successfully adopt an electronic trading system? Why did the leading auctions allow the Tele Flower auction to reframe competition among the auctions? In part, the various electronic initiatives of the traditional auctions did not fulfill compelling needs among the different stakeholders. In addition, the IT-based trading initiatives were embedded in a specific organizational context and set of assumptions that limited the initiatives.

Historically, the Dutch grower cooperatives have owned the auctions and have been the dominant influence on the use of technology in the auctions. The wellorganized growers who own the auction intermediary established a consensus on the trading rules and organization that best favored specific grower groupsfrom clock speeds to auction mechanism.

The technology-enabled initiatives of the existing auctions, with the exception of the Holland Supply Bank, generally assumed the existing valuation model and auction structure. As auction officials mentioned to us in interviews prior to the Tele Flower initiative, it was unlikely that any other form of trading or price discovery mechanism would be approved by the owners other than the Dutch auction. The innovations were thus embedded within the context and framework of the traditional auction model. Converting this model to an IT-based representation had the potential for a number of advantages to sellers. For example, by having a very fast auction clock, and trading in small lots in the traditional auction, the sellers found they could get higher prices. Electronic trading that preserved these features benefits the sellers but creates more costs for larger buyers, who are increasingly important in the market. Other price discovery mechanisms and trading rules, including larger lots, can be more efficient for large buyers.
As buyers become more powerful, and move to bypass the auctions or source foreign flowers, the existing consensus auction arrangement is being renegotiated. For example, by not participating in the sample auction, the buyers were able to influence the restructuring of the sample-based auctions. Second, the Holland Supply Bank brokered market represents another new arrangement for large buyers. Finally, the Tele Flower auction was the EAF and the buyers' response to restrictive foreign flower trading rules in the traditional Dutch flower auctions. The latter was a departure from renegotiating the consensus around a specific auction to creating a competing structure. This structure was created because the traditional auctions were forced to restrict the sale of foreign flowers by their owners.

The emergence of Tele Flower is especially instructive. Despite the advice of the traditional Dutch Auction officials, the owners voted to deny access to foreign growers. The subsequent creation of the Tele Flower auction resulted in the loss of a key revenue stream to the existing auctions and its owners. Conforming to the existing auction models limited innovation by the traditional Dutch auctions. In contrast, information technology allowed the EAF to coordinate and implement trading processes without colocation and at lower costs than setting up a facility similar to the traditional Dutch auctions. As buyers and foreign growers implement and continue to innovate in developing alternate markets, they will, most likely, increasingly reshape the access, price determination and trading rules to their favor. The emergence of Tele Flower could probably have been avoided if the buyers had an ownership stake and greater influence in the traditional Dutch auctions. This would have led to less biased or restrictive trading practices. We expect that information technology will enable new trading patterns that are less biased in favor of Dutch growers. These new trading models (e.g., clearinghouse auctions, brokered markets) could better serve different buyer segments.

In summary, current owners of the auctions may not have sufficient incentives to adopt new or more efficient auction mechanisms. The capacity of existing market structures to adapt to new electronic and nonelectronic innovations will be determined by the relative power and capabilities of different parties to the 
trade, the current ownership structures, and potential of competitive entry. In the Dutch auctions, we see an increasing shift of power toward buyers as new sources of supply become available, buyers become larger, and technology enables new low-cost trading mechanisms leading to competing markets.

\section{Conclusions}

This paper makes four key contributions to the literature on information technology and markets. First, we identify a series of distinct processes that underlie exchange relations. In contrast to the traditional case studies of electronic markets, this categorization provides a useful basis for examining how technology innovations affect specific trading processes. Second, we propose and illustrate the use of the process-stakeholder analysis framework for comparing different forms of trading, and evaluate the impacts on different market participants. This is a useful guide for designers of new market systems as well as those studying markets to evaluate or explain the successes and failures of IT-based initiatives in new markets. Third, the development of a detailed case study of market change and a cross-case analysis of IT initiatives in the Dutch flower markets result in a series of testable propositions. The propositions address the separation of physical and informational processes in trading, the responses of stakeholders to changes in information in markets due to IT initiatives, and economic and incentive conditions required for adoption of new trading processes. Finally, we propose a more complex and subtle view of markets than typically analyzed in the MIS literature.

While there are a number of teaching and research cases on electronic markets, these are either unsuitable for generating new theories (Kambil and Short 1994) or articles analytically apply transactions cost or network externality models to emergent markets (Bakos 1991b, Lee 1996). While some of the analysis provides conditions for market adoption, they shed little light on why different actors failed to adopt new market forms. In contrast, the rich cases in this study illustrate that markets represent a socially constructed consensus that is constantly renegotiated among stakeholders with different levels of power. Information technology, by enabling new low-cost trading mechanisms and changing information available to stakeholders, is one factor that can alter the relative costs and benefits to actors, or the power of actors leading to a renegotiation of the consensus. When the renegotiation fails, the new market form is not adopted. As new information technologies make feasible new models of electronic commerce, our analysis suggests that designers of new markets should carefully manage the context in which they apply their technologies by constructing suitable incentives and processes to arrive at a consensus.

Finally, the paper provides new tools and directions for inquiry for managers and researchers of electronic commerce. First, the process-stakeholder framework allows managers and researchers to systematically characterize process changes and the allocation of costs and benefits from electronic commerce. Second, the cases highlights new questions for research. As the Internet evolves to a powerful and reliable infrastructure for electronic commerce, Dutch auctions become more important as a trading mechanism. However, there is little published empirical research on the Dutch auction mechanism and the effects of clock speed, and other information variables on equilibrium prices, buyer strategies, and the distribution of benefits. New development tools (Java, etc.) will enable researchers to develop simulations and test market designs over the Internet to develop a richer understanding of individual behaviors in electronic markets. ${ }^{5}$

\footnotetext{
${ }^{5}$ We thank Hank Lucas, Ted Stohr, and the anonymous reviewers of Information Systems Research for their comments and suggestions on previous versions of this manuscript.
}

\section{References}

Akerlof, G. A., "The Market for 'Lemons': Qualitative Uncertainty and the Market Mechanism," Quarterly J. Economics, 84 (1970), 488-500.

Arrow, K. J., Limits of Organization, Norton, New York, 1974.

Bakos, J. Y. "Information Links and Electronic Marketplaces: The Role of Interorganizational Information Systems in Vertical Market," J. Management Information Systems, 8, 2 (1991a), 31-52. , "A Strategic Analysis of Electronic Marketplaces," MIS Quarterly, September (1991b), 107-119.

Blau, P., Exchange and Power in Social Life, John Wiley \& Sons, New York, 1964.

Bos, J., “De Klok met Afstandsbediening," Groot Handelsblad, November (1995), 22-23.

— , "Een Jaar TFA: De Innovatieve Noodsprong," Groot Handelsblad, March (1996), 8-11. 


\section{KAMBIL AND VAN HECK}

Brynjolfsson, E., T. W. Malone, V. Gurbaxani, and A. Kambil, “Does Information Technology Lead to Smaller Firms?", Management Sci., 40, 12 (1994), 1628-1644.

Clemons, E. K. and B. Weber, “London's Big Bang: A Case Study of Information Technology, Competitive Impact, and Organizational Change," J. Management Information Systems, 6 (1990), 4160.

— and - "Evaluating the Prospects for Alternative Securities Markets," in Proc. Twelfth International Conf. on Information Systems, New York, 1991.

Coase, R. H., "The Problem of Social Cost," J. Law and Economics, 3 (1960), 1-44.

Coase, R. H., "The Nature of the Firm," Economica, 4 (1937), 386-405.

Daft, R. L. and R. H. Lengel, “Organizational Information Processing Requirements, Media Richness and Structural Requirements," Management Sci., 32, 5 (1986), 554-571.

Dahlman, C. J., "The Problem of Externality," J. Law and Economics, 22, 1 (1979), 141-462.

Davis, D. and C. Holt, Experimental Economics, Princeton University Press, Princeton, NJ, 1993.

Eisenhardt, K. M., "Building Theories from Case Study Research," Acad. Management Rev., 14, 4 (1989), 532-550.

Eras, P., "Tele Flower Auction Veilt via Telefoon en Beeldscherm," Telecommagazine, 10, 10 (1995), 40-43.

Fukuyama, F., Trust-The Social Virtues and the Creation of Prosperity, The Free Press, New York, 1995.

Galbraith, J. R., “Organization Design: An Information Processing View," 4, 3 (1974), 28-36.

Griffioen, A., "Goede Start Informatieveilen in Aalsmeer," Vakblad voor de Bloemisterij, 2 (1994a), 9.

—, "Informatieveilen Moet de Stagnatie Overwinnen," Vakblad voor de Bloemisterij, 7, (1994b), 56-57.

Gurbaxani, V. and S. Whang, "The Impact of Information Systems on Organizations and Markets," Comm. ACM, 34, 1 (1991), 5973.

Homans, G., Social Behavior: Its Elementary Forms, Harcourt, Brace and World, New York, 1961.

Johnston, R. and P. R. Lawrence, "Beyond Vertical Integration-The Rise of the Value-Adding Partnership," Harvard Business Rev., 66, 4 (1998), 94-101.

Kambil, A., "Electronic Integration: Designing Information Technology Mediated Exchange Relations and Networks," Doctoral Dissertation, Sloan School of Management, Massachusetts Institute of Technology, Cambridge, MA, 1992.

— and J. E. Short, "Electronic Integration and Business Network Redesign," J. Management Information Systems, 10, 4 (1994), 59 83.

Klein, B., R. Crawford, and A. Alchian, “Vertical Integration, Appropriable Rents and the Competitive Contracting Process," $J$. Law and Economics, 21 (1978), 297-326.

Konsynski, B., "Thinking of Linking: Managerial Perspectives on Electronic Linkages Across Organizations," in Proceedings of Sci- entific Research on EDI, R. J. Streng, C. F. Ekering, E. van Heck, and J. F. Schultz (Eds.), Samson Bedrijfs Informatie, Alphen aan den Rijn, Netherlands, 1992.

— and A. Warbelow, "American Gem Market System," Case Study, 9-190-001, Harvard Business School, Cambridge, MA, 1989.

— and —_, "Cooperating to Compete: Modelling Interorganizational Interchange," Harvard Business School, Cambridge, MA, 1990.

—_ - , and J. Kokuryo, "AucNet", Case Study, 9-190-001, Harvard Business School, Cambridge, MA, 1989.

Lee, H. G., "Intelligent Electronic Markets for Commodity Auction: An Integrated Approach of Economic Theory and Social Choice Theory," Ph.D. Dissertation, University of Texas, Austin, TX, 1993.

_ _ "Electronic Brokerage and Electronic Auctions: The Impact of IT on Market Structures," in Proc. Hawaii International Conf. on System Sciences, Honolulu, Hawaii, 1996.

Malone, T. W., J. Yates, and R. I. Benjamin, “Electronic Markets and Electronic Hierarchies," Comm. ACM, 30 June (1987), 484-497.

Milgrom, P. and D. J. Roberts, "Bargaining Costs, Influence Costs, and the Organization of Economic Activity," in J. Alte and K. Shepsle (Eds.), Perspectives on Positive Political Economy, Cambridge University Press, Cambridge, England, 1990.

Powell, W. W., “Neither Market nor Hierarchy: Network Forms of Organization," Organizational Behavior, 12 (1990), 295-336.

Spooner, I. and D. Copeland, "Flower Auction Westland: The Cosmos Project," Case Study, University of Western Ontario, Canada, 1992.

Tushman, M. L. and D. A. Nadler, "Information Processing as an Integrating Concept in Organization Design," Acad. Management Rev., July (1978), 613-624.

Van Heck, E. and T. P. Groen, “Towards an Electronic Flower Auction?," in Proc. Management Studies and the Agri-business 1994: Management of Agri-chains, Wageningen Agricultural University, Wageningen, 1994.

— and P. M. A. Ribbers, “Economic Effects of Electronic Markets," Discussion Paper, No. 9669, Center for Economic Research, Tilburg University, The Netherlands, July, 1996.

—, E. Van Damme, J. Kleijnen, and P. Ribbers, “New Entrants and the Role of Information Technology, The Case of the Tele Flower Auction in the Netherlands," in Proc. Hawaii International Conf. on System Sciences, Vol. 3, IEEE Computer Society Press, Los Alamitos, CA, 1997.

Van Vliet, C., "EAF wil Met Importveiling Centrum Bloemenhandel in Nederland Houden," Vakblad voor de Bloemisterij, 49, (1994), $40-41$.

Williamson, O. E., Markets and Hierarchies: Analysis and Antitrust Implications, The Free Press, New York, 1975.

- The Economic Institutions of Capitalism: Firms, Markets and Relational Contracting, Free Press, New York, 1985.

Yin, R. K., “The Case Study Crisis: Some Answers," Admin. Sci. Quarterly, 26 (1981), 58-61.

Jiro Kokuryo, Associate Editor. This paper was received on April 11, 1995 and has been with the authors 10 months for 1 revision. 